\title{
Provide History Of Religion And God
}

Nicholas P. Ginex, New York University, USA

\begin{abstract}
There is a need for high school, college, and university educators to introduce their students to a history of mankind's development of religions and beliefs in God. Regarded as too sensitive a subject, students are deprived of learning how mankind has evolved ways to establish moral and righteous behavior to maintain harmony among competing groups within a growing community. Based upon facts and findings surfaced by such respected Egyptologists as James H. Breasted and E.A. Wallis Budge, this author conclusively reveals how the first formal religion of Egypt has been emulated by the Judaic, Christian, and Islamic religions. Historical findings provide meaningful evidence of the spiritual nature of man, the emergence of one God Amen, the development of the concepts of truth, a soul, hereafter, Son of God, and a universal God. These findings afford greater insights in the fields of theology, humanities, psychology, and sociology studies. More importantly, a greater understanding of the nature of man can energize religious leaders and the public to effect possible solutions with the assistance of those with perceptive minds and love of humanity.
\end{abstract}

Keywords: Religions; Amen; God; Truth

\section{INTRODUCTION}

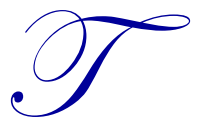

here is lacking in our educational system across the United States a curriculum that teaches and emphasizes the attributes of integrity based upon honesty and truth. Where and when did such attributes of truth, justice, and righteousness evolve? Was it revealed to mankind as revelations from God or developed by the experiences of different communities interacting with one another to establish harmony between their people? Our educators can provide answers to their students based upon an ancient civilization that created awe inspiring temples, pyramids and monuments due to their beliefs that embodied the attributes of truth, righteousness, and justice.

The purpose of this paper is to motivate educators to examine the book Future of God Amen for use in their classrooms. It offers a wealth of historical information of the development of Egypt's civilization and religious beliefs. The author proceeds to reveal how their beliefs were emulated by other groups of people to develop the major religions of today; namely, the Judaic, Christian, and Islamic religions. In addition, a comprehensive critique of the Torah, Gospels, and the Qur'an is given to demonstrate the connectivity of these scriptures to Egyptian hymns and religious beliefs. Finally, the author takes the reader further to study recommendations and solutions of the differences in religious beliefs that have created bigotry, hatred, violence, and the killing of innocent people.

\section{THE TRUE MEANING OF AMEN}

Knowledge is attained by reading, listening, and learning from the wisest of our elders and teachers. But to be able to discern what is significant and resounds as closely to the truth as is possible requires a sensitivity and disposition to compare, scrutinize, and evaluate the information with a sense of honesty. Many teachers are highly intelligent, but due to not receiving all the facts, they may be advocating erroneous information to their pupils. Only after exposure to new information they may find that they duplicated the ignorance of their teachers. This is the case of many Judaic and Christian leaders who have not been able, due to their lack of history, or knowingly are unwilling, to reveal the true meaning or significance of the words by Jesus Christ. In Revelation 3:14 of the New Testament, Jesus proclaimed Amen as "the faithful and true witness, the beginning of the creation of God". 
To understand the significance of Jesus's words, we need to know what “Amen” means or represents.

\section{Is Amen a Word or a Revered God?}

It is known that Judaic, Christian, and Islamic worshippers announce "amen" at the end of a prayer, supplication, expression of thanks and praise, and even sing "Amen, Amen, Amen". Yet few of these worshippers know that Amen was the greatest Egyptian God for over two thousand years before the birth of Jesus. Perhaps we should not fault religious leaders for their ignorance about the past because the hieroglyphic code was broken less than two hundred years ago, and Egyptologists have deciphered what was written on Egyptian tombs and temples only since the early1900s.

Religious leaders of the three monotheistic religions - Judaism, Christianity, and Islam - have not instructed modern man where and how "amen" originated. Most people are familiar with the definition taught by the monotheistic religions - "So be it" - which is in agreement with the definition of "amen" in Webster's Ninth New Collegiate Dictionary (copyright 1987). Unfortunately, it falls far short of the definitions provided in the Britannica World Language Dictionary (Funk and Wagnall's Standard Edition, 1959 Edition):

- Webster's “Amen” - used to express solemn ratification (as of an expression of faith) or hearty approval (as of an assertion)

- $\quad$ Britannica's "Amen" - $n$. So it is; so be it. 1. The word amen at the end of a prayer or hymn, meaning so be $i t$. 2. Any expression of hearty consent or conviction. 3. A concluding act or word; termination. - vt.

$\circ$ To say amen to; express hearty concurrence in or approval of.

- To say or write the last word of. Adv. Obs. Verily; truly. [< Greek, < Hebrew, verily]

- $\quad$ Britannica's "Amen" - $n$. Christ, the true and faithful witness. Revelation 3:14

- Britannica's "Amen” - $n$. In Egyptian mythology, the god of life and procreation represented as having a ram's head; later identified with the sun god, as the supreme deity, and called Amen-Ra. Also spelled Ammon, Amon (and Amun, Amoun, and Imen).

In addition to "So be it", the Hebrew usage of "amen" includes truth, to trust or believe, firm or faithful, true, verily, etc. In Isaiah 65:16, emphasis is on truth as "the God of truth", which is "the God of Amen". This usage is consistent with the ancient Egyptians' reverence for truth for it was the most esteemed attribute of their god Amen. Before we review the origin of Amen, it will be instructive to return to some of the definitions given above.

So Be It

The interpretation of "amen" as "so be it" is somewhat 'wanting' because it does not apply in all cases. For example, if we were thanking God for anything that has transpired that gave us peace, happiness, health, or a favorable outcome, to say "so be it" would be out of place because the good fortune has already occurred. "So be it" would be applicable as a supplication for something requested for the future or a prayer that emphasizes the need for God's help. When one exclaims "amen" as a hearty approval of something, then the connotation "so be it" does not apply. Rather, a thankful acknowledgment to God, by simply announcing his name, Amen, would be more appropriate. "So be it" does not convey thankfulness to God for your good fortune.

An Egyptian translation of "amen" means "the hidden one" and was associated with the air we breathe or the god of air. As such, the Egyptians sensed or felt the air manifesting itself as gusts of wind, but the god remains unseen and without form. The true nature of this god is therefore a mystery; he is unknowable and incomprehensible to human beings. Usage of "amen" by the Hebrews as meaning verily and true reflects truth, which is the most revered attribute of the Egyptian god Amen. In the next subsection we will conclusively find that "amen" originated with the Egyptians and not with the Hebrews.

\section{Amon As the Sole God}

During the reign of Ramses II (1292-1225), the Priesthood of Amon created a long hymn in praise of their imperial god, Amon-Re. After exposure to the concept of one god by Ikhnaton (Amenhotep IV, 1375-1358 BCE), 
the Priesthood wrote the hymn, Amon As the Sole God. ${ }^{1}$ The following extracts illustrate their perceptions of god and emphasize that Amen was highly revered as the one God of all creation.

\author{
Amon As the Sole God, 100th Stanza
}

The first to come into being in the earliest times. Amon, who came into being at the beginning, so that his mysterious nature is unknown. No god came into being before him; there was no other god with him, so that he might tell his form. He had no mother, after whom his name might have been made. He had no father who had begotten him and who might have said: "This is I!" Building his own egg, a daemon mysterious at birth who created his (own) beauty, the divine god that came into being by himself. All (other) gods came into being after he began himself.

\title{
Amon As the Sole God, 200th Stanza
}

Mysterious of form, glistening of appearance, the marvelous god of many forms. All (other) gods boast of him, to magnify themselves through his beauty, according as he is divine. Re is united with his body. He is the great one who is in Heliopolis. . .

The procreator of the primeval gods, who brought Re to birth; he completed himself as Atum, a single body with him. He is the All-Lord, the beginning of that which is. His soul, they say, is that which is in heaven . .

One is Amon, hiding himself from them, concealing himself from the (other) gods, so that his (very) color is unknown. He is far from heaven, he is absent from the underworld, (so that) no gods know his true form. His image is not displayed in writings. No one bears witness to him . . He is too mysterious that his majesty might be disclosed, he is too great that (men) should ask about him, too powerful that he might be known. Instantly (one) falls in a death of violence at the utterance of his mysterious name, unwittingly or wittingly...

To the Egyptian belief that Amon is the sole god, "the All-Lord, the beginning of that which is", it is Jesus Christ that confirms Amen as "the beginning of the creation of God". The above exposition provides how a distortion of the origin of Amen has been caused by religious leaders who control the hearts and minds of their worshippers rather than imparting truth and wisdom. It is one of the reasons to revise the present Scriptures to deal with the loving aspects of God without fear and admonitions to induce belief. This approach may have been necessary in the early stages of social development, when the priests and pharaohs used it to create a common unity to strengthen their new civil, political, and religious orders. However, it is to be noted that the Egyptians did not force religion upon their people; it was a natural outgrowth of thousands of years of humans learning to live together as one nome absorbed or overtook another in an environment isolated from the rest of the world.

It is foolish to ignore and distort the belief in Amen; a god that originated within the Egyptian civilization. To do so deprives believers of the complete history of their faith. To understand how the belief in God developed and why they announce Amen today brings respect and greater trust in their religious institutions. There is no shame to inquire about God and to learn about mankind's spiritual nature. The religious leaders of the Judaic, Christian, and Islamic religions have got to acknowledge that Egyptian concepts and beliefs form the core of their present religious beliefs. They have denied what they have learned from the Egyptians simply because they wanted to form unique and separate religions for their own people. While there is nothing wrong with individuality, not acknowledging the contributions by the first formal religion of the world discredits, rather than elevates, a religion and its leaders.

Amen in the Throne Names of Pharaohs

Starting with the Twelfth Dynasty (2000-1788 BCE), pharaohs began to use "Amen" in their throne names as they revered the solar god Re. By the Eighteenth Dynasty, Amon-Re came to be worshipped as the principal god of Thebes, the capital of Egypt. Table 1 lists the pharaohs known to have used "Amen" and "Amon" in their throne names for more than 1,000 years, starting as early as 2,000 BCE.

\footnotetext{
${ }^{1}$ Pritchard, James B, ed. By. (1955) Ancient Near Eastern Texts, Amon As the Sole God. Princeton University Press. Princeton,
} New Jersey. 368-369.

2013 The Clute Institute http://www.cluteinstitute.com/ 
To end this exposition that reveals the true meaning of Amen, it is worthy to illustrate the depth and beauty of Egyptian scripture by providing a few excerpts from A Hymn to Amon-Re. It was deciphered from the Boulaq Papyrus residing in the Cairo Museum, dated sometime between 1580-1350 BCE, a period after the Hyksos were defeated and the end of Amenhotep IV's reign (1375-1358).

Table 1: Throne Names of Pharaohs with Amen or Amon

\begin{tabular}{|c|c|c|c|}
\hline King/Pharaoh & Reign Years (BCE) & Years & Commentary/Remarks Derived from Throne Name \\
\hline Amenemhet I & $2000-1970$ & 30 & 20 years alone, 10 years with son. \\
\hline Amenemhet II & $1938-1903$ & 35 & $\begin{array}{l}3 \text { years with his father, } 29 \text { years alone, } \\
3 \text { years with his son. }\end{array}$ \\
\hline Amenemhet III & $1849-1801$ & 48 & Uncertain years with father and son. \\
\hline Amenemhet IV & $1801-1792$ & 9 & Uncertain period with his father. \\
\hline $\begin{array}{l}\text { Amenemhet V } \\
\text { (Amen Intef IV) }\end{array}$ & ( ? ) -1770 & $?$ & *The Heart of Re Lives. \\
\hline Amenhotep I & $1557-1547$ & $10+\mathrm{x}$ & *Holy is the Soul of Re. \\
\hline Amenhotep II & $1448-1420$ & $26+x$ & $\begin{array}{l}\text { Father, Thutmose III. } \\
* \text { Great are the Manifestations of Re. }\end{array}$ \\
\hline Amenhotep III & 1411-1375 & 36 & *Lord of Truth of Re. \\
\hline $\begin{array}{l}\text { Amenhotep IV } \\
\text { Changed his name to } \\
\text { Ikhnaton. } \\
\text { Also known as } \\
\text { Akhenaton. }\end{array}$ & $1375-1358$ & $17+\mathrm{x}$ & $\begin{array}{l}\text { Mother Tiy, wives Nefertiti, Kiya, Merytaten, } \\
\text { Ankhesenpaaten, Mekytaten. } \\
\text { Son Tutenkhamon by Kiya. } \\
\text { *Beautiful are the Manifestations of Re. Servant of the Aton. }\end{array}$ \\
\hline Tutenkhamon & $1357-1353$ & $4+x$ & *Lord of Manifestations of Re. \\
\hline Amenmesses & 1215 & $\mathrm{x}$ & $\begin{array}{l}\text { Father Merneptah. } \\
\text { * Eternal Like Re, Chosen of Re. }\end{array}$ \\
\hline Amenemopet & $1026-976$ & $49+x$ & $\begin{array}{l}\text { *Powerful is the Justice of Re, Beloved of Amon, Chosen of } \\
\text { Amon. }\end{array}$ \\
\hline Siamon & $976-958$ & $16+\mathrm{x}$ & *Like a God is the Manifestation of Re, Chosen of Amon. \\
\hline
\end{tabular}

\section{A Hymn to Amon-Re}

Hail to thee, Amon-Re, ...Lord of what is, enduring in all things, enduring in all things, ...Lord of eternity, who made everlastingness... Who made what is below and what is above,

The chief one who made the entire earth,... Thou art the sole one, who made all that is, [The] solitary sole [one], who made what exists...

Father of the fathers of all the gods, Who raised the heavens and laid down the ground, Who made what is and created what exists;...

Maker of all mankind, Creator and Maker of all that is...

The above hymn conclusively reveals that the Egyptians formulated the belief in one universal God, the "Creator and Maker of all that is". In the following subsection, a brief summary is presented to provide an overview how mankind learns from former generations and adapts religious beliefs that serve to improve the morality of their own people.

\section{SCRIPTURE EVOLVES AS MAN GAINS KNOWLEDGE}

When the Egyptian priesthood first formulated the concept of creation by god, it could not be precisely dated, but it was defined prior to the founding of the First Dynasty. This profound concept was carved inside the pyramids of Merne-Re I and Pepi II (Nefer-ka-Re) built during the Sixth Dynasty, around 2540 BCE. An overview of recorded documents and when the transformations took place is presented in Figure 1. For a detailed history of the transformations of the creator god Atum to the belief of one universal god, the reader may refer to the historical novel Future of God Amen. An understanding of how the belief in one universal god developed would not be complete without reading significant extracts of the hymns depicted in Figure 1. 


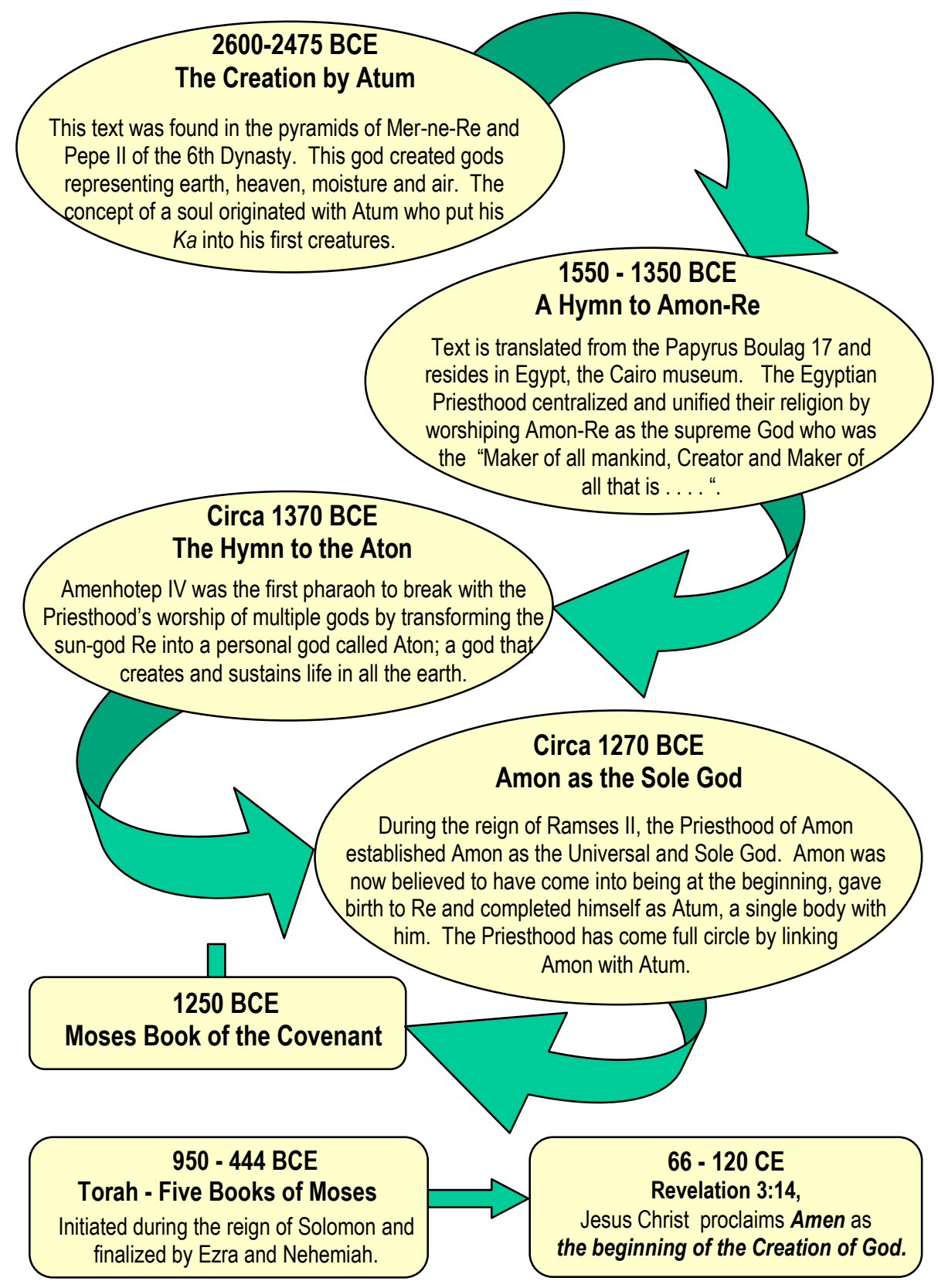

Figure 1: Scripture Evolves as Man Gains Knowledge

\section{A Critique of the Monotheistic Scriptures}

Religious scholars and educators that have studied Egyptian history are knowledgeable of the influence of Egyptian scripture in the creation of Genesis and many of the Old Testament psalms and proverbs. This knowledge does not stop with Genesis because the core commandments received by Moses from God had already been practiced by the Egyptians since the Predynastic Period. By subtracting the date Moses wrote the Book of the Covenant from the end of the Predynastic Period, or 3400-1250 BCE, we find that more than two thousand years had elapsed before the moral code of the Egyptians were adapted by the Hebrews. 
Genesis Contains Concepts/Verses From Egyptian Scripture

Future of God Amen presents how significant verses in the Hymn to the Aton by Amenhotep IV and the ReIsis Myth (circa $1300 \mathrm{BCE}$ ) resurfaced in the first chapter of Genesis.

History Provides A Link For The Writing Of The Gospels

An in-depth study is provided to reveal reasons why the Gospels were written around the start of the Jewish-Roman War (May of $66 \mathrm{CE}$ ) and well after the destruction of the Jewish nation and near dissemination of their people.

The Gospels present areas of discussion for instructors to have their students analyze and determine the relevancy of the Trinity and whether Jesus was a Son of Man or a Son of God. Revelation in the New Testament provides confirmation by Jesus Christ that validates the main theme of Future of God Amen; namely, that Amen is "the faithful and true witness, the beginning of the creation of God". Commentary of these scriptures by the author compelled the author to perform a line-by-line review of the Qur'an. Following are some of the findings that surfaced by such a review.

\section{The Islamic Empire Rises Using Force}

The Qur'an was not revealed to Muhammad in a short period of time as it was to Moses, who quickly transcribed what he heard from God in the Book of the Covenant (Exodus 24:4-8). Rather, Muhammad, who had not learned to read or write, had committed his revelations from the angel Gabriel to memory. It was some twenty years after Muhammad's death that a religious group of leaders compiled his revelations into the first official document. This religious group, uniquely identified in the Qur'an, put the longest suras (chapters) at the beginning and the shortest at the end.

In just twenty-nine years from the death of Muhammad (661-632 CE), the Muslims had established an empire. The first caliph had been concerned only with spreading Islam among the Arabs in Saudi Arabia. Motivated by power and wealth, by $1300 \mathrm{CE}$, the Muslim leaders forced conversion to Islam not only in the Byzantine and Persian empires, but also as far west as Spain and all of North Africa, including its east coast down to the island Madagascar and further east to the northern half of India.

\section{The Qur'an Sanctions Fighting and Killing}

In sura 2:217-219, there is a defense for fighting and killing people who incite disorder by denying Allah or profaning the sanctity of the Sacred Mosque.

Sura 2:217-219. Fighting is ordained for you, while it is repugnant to you. It may be that you dislike a thing which is good for you, and it may also be that you prefer a thing and it may be the worse for you. Allah knows all and you know not. They enquire from thee about fighting in the sacred month, Say to them: Fighting in it is a great evil, but to hinder people from the way of Allah and to deny Him and to profane the sanctity of the Sacred Mosque, and to turn out its people therefrom is a much greater evil in the sight of Allah; and disorder is a worse evil than killing.

\section{The Qur'an Sanctions A Party to Forbid Evil}

Not obvious to the average reader or devout follower of the Qur'an is that it was some twenty years after Muhammad's death that a religious group gathered and assembled his revelations to form the Qur'an. More importantly, they also incorporated into the Qur'an a party whose business is to invite goodness, enjoin equity, and forbid evil. This party is uniquely sanctioned in the Qur'an by the sura verse below.

Sura 3:105. Let there be from among you a party whose business it should be to invite goodness, to enjoin equity and to forbid evil. It is they who shall prosper. 
This sura provides a clear statement that a party of religious leaders is authorized to enforce their judgment and any necessary actions to act in the name of Allah. The following subsections will reveal that, indeed, there is a party of men that, throughout the Qur'an, are repeatedly identified with the plural pronouns "we", "our", and "us".

\section{A Party throughout the Qur'an is identified as "We, Our and Us"}

Is the party, identified herein as the "We Party", Allah? In sura 7:5-7, the We Party reveals themselves as responsible for the destruction of many towns in the name of Allah who is most gracious and ever merciful - a contradiction of a loving God.

Sura 7:5-7. Little is it that you heed. How many a town have we destroyed! Our punishment came upon their dwellers by night or while they slept at noon. When our punishment came upon them all they could utter was: We are indeed wrongdoers.

This and the following sura again emphasize the killing of disbelievers - people who did not spill blood but simply believed in their own god. Note the planned strategy of killing innocent people while they are asleep at night, noon, or at play. Also note below that the We Party attributes this atrocity to the "design of Allah".

Sura 7:97-100. We afflicted them suddenly with chastisement, while they perceived not the cause thereof. If the people of those towns had believed and been righteous, we would surely have bestowed blessings upon them from heaven and earth, but they rejected the Prophets, so we seized them because of that which they did. Do the people of these towns now feel secure against the coming of our punishment upon them by night while they are asleep? Or, do they feel secure against the coming of our punishment upon them in the forernoon while they are at play? Do they feel secure against the design of Allah? None feels secure against the design of Allah, except those that are losers.

The above suras violate a basic commandment - "Thou shalt not kill". Under no circumstances should a holy book convey the killing of our sisters and brothers in the name of, or by the design of, God. The above suras rationalize such killing and present a ruthlessness and disregard for God's creations. It is another example of the We Party speaking for God.

\section{RECOMMENDATIONS FOR RELIGIOUS LEADERS AND WORSHIPPERS}

Religious leaders of the three basic faiths must put aside dogmatic reasons for having their people believe their god is unique to them only. It is the name Amen that has survived over four thousand years and reigns over Yahweh and Allah. Yahweh is a god who dwelt on the slopes of a wilderness mountain and descended upon it in fire and smoke. Allah is not the name of a god but an Arabic word meaning one god. When the three religions concede that God introduced himself to mankind as Amen, then they will acknowledge truth. The present definition for "amen" - "so be it" - should be revised and revered as the name of God. The following recommendations will cause much controversy. However, intelligent men with loving hearts for sisters and brothers around the world will be able to understand that long-held doctrines can be revised based upon reason and truth.

\section{The Three Basic Religions Worship The Same God} same God.

Religious leaders must be truthful and loudly proclaim that Jews, Christians, and Muslims all worship the

\section{The Name Of God Is Amen}

Men have conceived God in different stages and by different groups of people. The one-god concept was conceived as Atum who came into being by himself and was the creator of all things. Early man was so closely attached to and awed by the wonders of nature that he developed the worship of many gods. To break away from the past of multiple gods and develop the first one-god concept was a feat that could only be accomplished by a man in power; that man was the pharaoh Ikhnaton (Amenhotep IV). The Egyptian priesthood later took Ikhnaton's writings and formalized them into scripture that defined the god Amon as the creator of all things. It is remarkable that the 
name Amen is still pronounced at the end of a prayer, supplication, giving thanks, praise, and singing his name in reverent tones.

\section{The Three Basic Religions Must Open Their Doors To All People}

By having the same God, the leaders of Judaic, Christian, and Islamic religions are obligated to open the doors of their houses of worship to all those who believe in that same god. To restrict their temples, churches, and mosques to only those who subscribe to the practices and rites of their religion is to prohibit the children of God from seeking, inquiring, and learning more about the god they worship. The religious leaders who are proud of their practices and the doctrines they teach will surely welcome the sisters and brothers of any nation. If not, their religion is nothing more than a sham, a cult for arrogant human beings who believe that they are better than their sisters and brothers of other ethnic groups and countries.

\section{People Must Go To Each Other's House Of Worship}

It has been acknowledged that the three basic religions all pray to the same god. God has made himself known to different groups of people at different times so that they could eventually benefit in accepting God's Holy Spirit of compassion and love. Followers of Judaism, Catholicism, and Islam, and their many sects, have an opportunity to visit different houses of worship. Several benefits will be derived:

1. Worshippers will learn other aspects of their god and how he has revealed himself to his children.

2. Worshippers will learn why religious doctrines have been received differently for different peoples to serve their needs for moral direction.

3. By attending the services of different religions, people worldwide will be able to learn to appreciate the differences in how they worship the same god.

4. Rabbis, priests, ministers, caliphs, imams, and mullahs of Judaic, Christian, and Islamic religions will be able to teach sisters and brothers from different nations about their prophets and the holy scriptures.

5. The sermons from the religious leaders will be given more significance because, like businesses in competition with each other, they must reach within their beings to bring relevance from within their holy scriptures to their congregations.

6. Finally, the tolerance and respect people give to each other's religions will, in time, cause them to merge with a unified conception of their god and his commandments.

\section{Religions Must Update And Improve Their Holy Scripture}

The revision of outdated dogma is not sacrilegious or blasphemous as strict religious leaders would like people to believe. Figure 1 reveals that the Egyptians evolved the conception of one creator god beginning with Atum.

After Ikhnaton implemented the concept of one god, Aton, about 1370 BCE, the Priesthood of Amon updated their religious scripture in $1270 \mathrm{BCE}$ and proclaimed Amon as the sole god. Twenty years later, in 1250 BCE, Moses walked out of Egypt with worshippers that believed in one god. His conversations with God were recorded in the Book of the Covenant, which initiated the Torah during Solomon's reign around 950 BCE. By 444 BCE, the Five Books of Moses were finalized by the efforts of Ezra and Nehemiah.

After the Jewish-Roman wars, which caused near annihilation of the Jews throughout Israel and complete destruction of Jewish towns and cities, a sect of Jewish holy men saw a need to salvage their legacy in the belief in one god. Their writings led to the creation of the New Testament. Therefore, holy scripture is not cast in concrete. Rather, it is revised due to critical events; but also, revisions become necessary as mankind grows in intellect, experience, and knowledge of the world around him. 


\section{Education And Science Are Essential Elements For Knowing God}

The most wonderful gift with which God has endowed mankind is an inquiring mind. Without it, people could not possibly possess the spirit to come to know him. The ideas of being all one can be, tapping into one's abilities and creative talents to make your creator proud, is what should be taught in every home and by every religion. It is through education and the sciences that people not only learn to understand themselves better, but also eliminate ignorance by exploring their world. The benefit will be a greater appreciation of how he has created life throughout the universe. Someday, if mankind is truly blessed, they may come face to face with intelligent aliens. It is knowledge that must be sought. Fear and the repression of knowledge can only lead to disbelief in God because the human spirit will be reduced to ignorance. Through exposure of the wonders of God's universe, people are sure to gain a greater understanding of themselves and God. By extending perception of God beyond heaven and earth to the expanse of the universe, all life will be revered and God becomes a greater reality.

\section{CONCLUSION}

This paper is not meant to advocate nor deprecate the beliefs of the Judaic, Christian, and Islamic religions. It has been written to invite educators to fill the void of truth based upon facts and findings to stimulate their students to think about a most important topic - God. How mankind has come to conceive one universal God and why the name of a god Amen continues to exist in the minds of men and women is worthwhile exploring and discussing in classrooms around the United States, albeit, the world.

Having a true perspective of the past, untainted by myths and dogma that have strayed from the revered beliefs of truth, justice, and righteousness, will improve clarity of mind and a mature understanding why we believe in a force that is incomprehensible, mysterious, and unknowable. This force has been conceived by mankind to follow a moral code and provide for their aspirations that may be attainable in the future.

The greatest contribution to the conception of God has originated within the Egyptian civilization. Other groups of people have emulated their beliefs in a soul, a hereafter, a Son of God, and finally one universal God of all creation. It remains for educators to teach the truth provided by the dedicated efforts of men who deciphered the hieroglyphics and brought to light a legacy that has not been acknowledged for the African people.

This author expresses with humility that he desires the support of educators to enlighten the world why we say Amen at the end of a prayer and teach history based upon facts and findings surfaced by Egyptologists. Let us not let their efforts be buried or let the ideas presented in Future of God Amen die due to biases that cannot be overcome. Complimentary copies of Future of God Amen may be requested to evaluate its contents by contacting the author via the website or e-mail provided below.

\section{AUTHOR INFORMATION}

Nicholas P. Ginex is a graduate of New York University with a BEE degree and an MBA in finance from Adelphi University in New York. He worked in design and distinguished himself in the support disciplines of Maintainability and Configuration Management (CM). As CM manager of software and hardware products at top aerospace and commercial companies, his writing, organizational, logical and analytical management skills produced plans, procedures, and supporting documents for the successful operation of entire engineering projects. E-mail: nickginex@gmail.com

The author may also be contacted via the website www.futureofgodamen.com, which provides an overview and book reviews of both historical novels, Future of God Amen and AMEN.

\section{REFERENCES}

1. Armstrong, Karen (1993). A History of God, New York, N.Y., Ballantine Books.

2. $\quad$ Breasted, James H (1933), The Dawn of Conscience, New York, N.Y., Scribner's Sons.

3. $\quad$ Breasted, James H (1935), A History of Egypt, New York, N.Y., Scribner's Sons.

4. Bruno, Giordano (1950), Giordano Bruno, His life and Thought, New York, N.Y., Henry Schuman.

2013 The Clute Institute http://www.cluteinstitute.com/ 
5. Budge, E.A. Wallis (1923), The Book of the Dead, London, England; Penguin Group.

6. Clayton, Peter A (1994), Chronicle of the Pharaohs, New York, N.Y., Thames and Hudson Inc.

7. Dimont, Max I (1962), Jews, God and History, New York, N.Y., Signet Books.

8. Freud, Sigmund (1967), Moses and Monotheism, New York, N.Y., Vintage Books div. of Random House.

9. Ginex, Nicholas P (2009), Future of God Amen. Bloomington, Indiana: Xlibris Corp.

10. Khan, Muhammad Z (1997), The Qur'an, Brooklyn, N.Y., Olive Branch Press ( $1^{\text {st }}$ translation in 1893).

11. King James Version (1978), Holy Bible, Red Letter ed., Nashville, Tennessee, Regency Publishing House.

12. La Barre, Weston (1972), The Ghost Dance, New York, N.Y., Dell Publishing Co., Inc.

13. Manji, Irshad (2004), The Trouble With Islam, N.Y., N.Y., Canada, Random House,St. Martin's Press.

14. Noss, John B. (1974), Man's Religions, $5^{\text {th }}$ ed., New York, N.Y., MacMillan Publishing Co.

15. Pritchard, James B (1955), Ancient Near Eastern Texts Relating to the Old Testament, Princeton University Press, $2^{\text {nd }}$ ed.

16. Sagan, Carl (1980), Cosmos, New York, N.Y., Random House Inc.

17. Smith, Homer W (1957), Man and His Gods, New York, N.Y., Grosset and Dunlap.

18. Spong, John S (2005), The Sins of Scripture, New York, N.Y., HarperCollins Publishers.

19. Vermes, Geza (1982), The Dead Sea Scrolls in English, Middlesex, England \& N.Y., Penguin Books, Ltd.

20. Whiston, William (2001), Antiquities of the Jews by Flavius Josephus, Elk Grove Village, U.S., Lightening Source Inc. 